\title{
Innovation management in consulting firms: identifying innovation processes, capabilities and dimensions
}

\section{Antonio Hidalgo*, Isaac Lemus-Aguilar and Alberto Urueña}

Department of Industrial Engineering,

Business Administration and Statistics,

Universidad Politécnica de Madrid, Spain

Email: antonio.hidalgo@upm.es

Email: isaac.lemus@upm.es

Email: alberto.uruena@upm.es

* Corresponding author

\begin{abstract}
Consulting firms are considered part of knowledge-intensive business services, in which expert knowledge plays a crucial input in the provision of service. Using a multi-case study, this study aims to improve understanding of how consulting firms strategically manage innovation processes and which capabilities and dimensions they focus on to deliver innovation, based on interaction among the main actors from both an internal and external perspective. Consulting firms tend to simplify reality, but several innovation processes take place at the same time. Results show that these views are not mutually exclusive; on the contrary, many of them coexist over the lifecycle of the firm and its particular business conditions. The challenge for innovation in consulting firms achieving a balance between generating incremental change by exploiting current knowledge and creating radical innovations by exploring new ideas at the same time.
\end{abstract}

Keywords: innovation management; innovation process; innovation capabilities; innovation dimensions; consulting firms.

Reference to this paper should be made as follows: Hidalgo, A., LemusAguilar, I. and Urueña, A. (20XX) 'Innovation management in consulting firms: identifying innovation processes, capabilities and dimensions', European J. International Management, Vol. x, No. y, pp.xx-xx.

Biographical notes: Antonio Hidalgo is full Professor of Technology Strategy, Director of the Innovation, IPR and Technology Policy research group (INNOPRO), and Director of the Master and Doctorate in Economics and Innovation Management at Universidad Politécnica de Madrid (UPM). $\mathrm{He}$ received an $\mathrm{MBA}$ and $\mathrm{ahD}$ in Industrial Engineering from the UPM. He have worked in several EU funded projects and participated as international consultant related to technological transfer in several projects financed by the World Bank and the Interamerican Development Bank. He is author of several books and papers about technology management published in different international journals. 
Isaac Lemus-Aguilar is a $\mathrm{PhD}$ candidate in the European Doctorate in Industrial Management (EDIM) at the Universidad Politécnica de Madrid (UPM) and Politecnico de Milano (POLIMI). He is also Assistant Professor in Innovation Management and Economics at UPM. He holds a BSc in Computer Systems for Management from InstitutoTecnológico de Monterrey (ITESM) in Mexico and an MSc in Strategic Project Management. Prior to academia, he worked as business consultant. His research interests involve areas of innovation management, strategy and services.

Alberto Urueña is Deputy Assistant Director of the National Observatory of Telecommunications and the Information Society and Professor of economics ad in the Universidad Politécnica de Madrid (UPM). He received a $\mathrm{PhD}$ in Industrial Engineering from the UPM in the programme of Economics and Management of Innovation. He earned an executive MBA from IE Business School and Masters in Economics of Telecommunications from Universidad Nacional de Educación a Distancia (UNED). His research interest in the Innovation, Industrial Property and Technology Policy (INNOPRO) research group is the study of information society and its impact on citizens and businesses.

\section{Introduction}

As an interdisciplinary science, service innovation needs to be analysed to help make innovation management more systemic and sustainable (Maglio and Spohrer, 2013). At present, developed economies, as well as many developing ones, are based on services, which in most of the cases comprise more than $70 \%$ of the country's gross domestic product (GDP) and more than $80 \%$ of total employment (OECD, 2005). One of the main strategic factors in the Europe 2020 strategy is innovation (Kaynak et al., 2017), and the European Union has decided to develop an economy based on knowledge and service innovation. It recognises that 'services and the service sector are increasingly important growth motors in the economy and account for more than two-thirds of employment and gross value added generated by the EU' (European Commission, 2012a, p.11).

Service innovation is a new service experience or service solution that consists of one or more dimensions, such as a new service concept, new customer interaction, new value system/business partners, a new revenue model and a new organisational or technological service delivery system (den Hertog et al., 2010). This definition refers to the service system viewpoint, which captures the essence of innovation as both a process (activities) and output (value proposition) and is the result of the ability and capacity to use resources (people, technology, knowledge and money) that are both internal and external to the firm. Service innovation is a driver of a productive economy and provides fuel for change in other industries.

The institutional context is important in the operation of innovation processes in general, in particular innovation management. This implies that innovation will work differently in different instructional environments, which is a research gap that needs to be filled with new frameworks (Phillips, 2013; Chesbrough and Bogers, 2014). It would be beneficial to understand which constructs apply to each type of service sector. 
Some service sectors - such as knowledge-intensive business services (KIBS), professional services firms (PSF) and project-based firms $(\mathrm{PbF})$ - are considered much more innovative than others, and many of them base their work on projects (Tether, 2013; Bouncken and Kraus, 2013). KIBS are the leading sub-sector regarding innovation and cooperation (Trigo and Vence, 2012), using multiple sources of information and co-producers of innovation (den Hertog, 2000). PSF is usually ambidextrous between exploitation and exploration activities because of the interconnection between product and process innovation, which is why PSF have an open innovation process to cooperate with clients (Smets et al., 2012; Morris et al., 2015). PbF are characterised by long project life cycles, in which the provision of the service often implies a close collaboration with its clients, which in turn reflects the contribution of a client to the innovation process (Salunke et al., 2011).

Consulting firms are an appropriate context for researching innovation in services because they incorporate, at the same time, the characteristics of KIBS, PSF and PbF that show a strong internal trend and a favourable environment for innovation. Anand et al. (2007) argue about the importance of consulting firms for knowledge-based innovation: the expertise and competence of their personnel are their primary assets, the widespread use of a partnership form of ownership, the inherent imperative for both organic growth and diversification in the context of innovation and continuous creation of new knowledge-based structures.

Traditionally, consulting firms are classified as intermediaries, that is, providers of knowledge and experience used to solve customer problems (den Hertog, 2000; von Nordenflycht, 2010). However, now consulting firms are moving towards activities to connect businesses. They are becoming the central axis of innovation ecosystems. Recent work reveals the emergence of an open innovation process that coexists with other processes (Öberg and Alexander, 2018). They identify the need for openness in companies and the creation of links with actors who were traditionally not involved in innovation in terms of sources (patents, acquisitions, mergers and R\&D alliances), markets (subcontracting, outsourcing and alliances) and shared activities (clusters, networks and joint ventures).

This research was carried out in the context of consulting firms, which have not received particular attention in academic research concerning innovation management (Fischer, 2011), and its main objective is to understand how consulting firms strategically manage the innovation process and which capabilities and dimensions they focus on to deliver innovation. The paper proceeds as follows: section 2 explains the theoretical framework used to understand the management of innovation in consulting firms; section 3 presents the research methodology based on a multiple-case study; section 4 summarises the results and argues about the main findings, and section 5 presents the conclusions.

\section{Theoretical background}

Most innovation studies have focused on explaining how an organisation can foster innovation based only on a particular variable, such as the innovation type (product/service, process and organisational) or the strategic innovation process (technology-push, market-pull and open innovation) (Verganti, 2010; Tidd and Bessant, 2013). Current innovation frameworks were first developed in manufacturing and have 
evolved from a longitudinal single process view to a network and cyclical perspective (Poutanen et al., 2016). With the rise of services, companies need to organise for innovation with the aim of creating new frameworks that address the nature of services which are co-produced with clients, unlike the development of new products (Droege et al., 2009; Crevani et al., 2011; Chatzoglou and Chatzoudes, 2017).

Lemus-Aguilar and Hidalgo (2015) summarise some recent perspectives stated by diverse authors:

- The novelty-oriented view: Service innovation consists of a reproducible, new or significantly improved service concept and offerings (European Commission, 2012b).

- The knowledge-oriented view: Service innovation is the extent to which the firm integrates new knowledge into service offerings, which directly or indirectly results in value for the company and its customers/clients (Salunke et al., 2012).

- The relational view: A service value network is a set of activities in which suppliers, service providers and customers integrate resources through services and co-create customer value in a specific cultural environment with a service provider value proposal (Chae, 2014; Hidalgo and D'Alvano, 2014).

- The system view: The service system is a dynamic value co-creating configuration of resources, including people, technology, organisations and shared information, connected internally and externally by value propositions, with the aim of meeting customer needs better than competitors do (Vargo and Lusch, 2004; Maglio and Spohrer, 2008).

Some researchers have a traditional product-oriented view, while others consider that services are intangible and separate from physical products, and yet others present a relational approach emphasising the role of customers and a network of actors as co-creators of service. Nevertheless, all the perspectives offer something novel that delivers value to the customer. In many cases, the success of manufacturing depends very much on innovative services, such as design, marketing and logistics, as well as on product-related after-sales services.

Few works provide frameworks for understanding the elements that firms must take into account in managing service innovation (den Hertog et al., 2010; Chae, 2012; Rubalcaba et al., 2012; Furseth and Cuthbertson, 2013; Hidalgo and D'Alvano, 2014). Table 1 presents a comparison of the main elements that these frameworks consider: dimensions, capabilities, processes and sources. Dimensions refer to the output of the innovation process (i.e. they are different forms that service innovation can take, such as a new service offering or a new business model). Capabilities refer to routines that an organisation develops to manage the innovation process (i.e. identifying client requirements, creating alliances and service conceptualisation). Processes involve a series of activities to guide the organisation in the management of service innovation (i.e. idea generation, idea implementation and service commercialisation). Sources refer to the different internal and external actors that can provide the necessary knowledge as input for the innovation process (i.e. managers, users and employees). 
Table 1 Recent frameworks for service innovation

\begin{tabular}{lccccc}
\hline $\begin{array}{l}\text { Service innovation } \\
\text { elements }\end{array}$ & $\begin{array}{c}\text { den Hertog } \\
\text { et al. (2010) }\end{array}$ & $\begin{array}{c}\text { Rubalcaba } \\
\text { et al. (2012) }\end{array}$ & $\begin{array}{c}\text { Chae } \\
(2012)\end{array}$ & $\begin{array}{c}\text { Hidalgo and } \\
\text { D'Alvano } \\
\text { (2014) }\end{array}$ & $\begin{array}{c}\text { Furseth and } \\
\text { Cuthbertson } \\
\text { (2013) }\end{array}$ \\
\hline $\begin{array}{l}\text { Dimensions } \\
\text { Capabilities }\end{array}$ & $\mathrm{X}$ & $\mathrm{X}$ & $\mathrm{X}$ & $\mathrm{X}$ & \\
Process & & $\mathrm{X}$ & & $\mathrm{X}$ & $\mathrm{X}$ \\
$\begin{array}{l}\text { Sources } \\
\begin{array}{l}\text { Citations Google } \\
\text { Scholar (July 2018) }\end{array}\end{array}$ & 572 & 149 & 84 & 36 & $\mathrm{X}$ \\
\hline
\end{tabular}

Two models are used to analyse the concepts in the exploratory case studies: the Model for Innovation Processes in Services (Rubalcaba et al., 2012) and the Six-Dimensional Service Innovation Model (den Hertog et al., 2010). These two models are selected for the following reasons: they cover the views on the four most common elements needed for service innovation identified in the literature review (dimensions, capabilities, processes and sources), and they have the highest number of citations on this research topic. For example, the Six-Dimensional Service Innovation Model is supported by empirical evidence for its generalisation by Janssen et al. (2016).

The Model for Innovation Processes in Services comes from the service stream and identifies three main processes involved in the innovation process of service firms: managers, employees and customers. The first process encompasses the strategy used by the management team to induce and balance innovation activities within the business. It includes tools, activities and structures to develop, promote, evaluate, foster and reward ideas. The second process involves the actions performed by employees during the provision of service. Employees play a crucial role in articulating customer interactions, the innovation mechanisms provided by the top management and their skills (i.e. knowledge, entrepreneurship, creativity and communication). The third process takes the customer from the role of service co-producer to service co-creator. Although the employee also remains important, this innovation process grows out of customer participation and the sharing of knowledge, problems and ideas.

The Six-Dimensional Service Innovation Model comes from the innovation/strategic management stream. This framework identifies six dynamic capabilities for realising new service experience and solutions (signalling user needs and technological options; conceptualising; (un-)bundling; co-producing and orchestrating; scaling and stretching; and learning and adapting) and covers possible dimensions in which service innovation can occur (new service concept, new customer interaction, new business partner, new revenue model, new delivery system [personnel, organisation, culture] and new delivery technology). This model hypothesises that successful service innovators, which may include manufacturing firms that develop into providers of service solutions, outperform their competitors in at least some of these capabilities.

Figure 1 shows the research framework used in this study based on the integration of the two selected models of service innovation. The dynamic capabilities of service innovation are the basis of the multiple innovation processes within a firm. These processes are initiated by different sources of innovation available to the firm according 
to its innovation strategy (managers, employees and customers), which in turn use dynamic innovation capabilities to generate one or more dimensions of service innovation as a result of the process.

Figure 1 Research framework

\begin{tabular}{|c|c|c|}
\hline $\begin{array}{l}\text { Dynamic scrvicc } \\
\text { innovation } \\
\text { capabilitics } \\
\text { - Signalling uscr nceds } \\
\text { - Conceptualising } \\
\text {-(Un-) bundling } \\
\text { - Co-producing and } \\
\text { orchestrating } \\
\text { - Scaling and stretching } \\
\text { - Learning and adapting }\end{array}$ & $\begin{array}{l}\text { Sources for service } \\
\text { innovation processes } \\
\text { - Manlagers } \\
\text { - Limployees } \\
\text {-Clients }\end{array}$ & $\begin{array}{l}\text { Service innovation } \\
\text { dimensions } \\
\text { - New service concept } \\
\text { - New customer intcraction } \\
\text { - New business partner } \\
\text { - New revenue model } \\
\text { - Ncw dclivery systcm } \\
\text { - New delivery techmological } \\
\text { system }\end{array}$ \\
\hline
\end{tabular}

\section{Methodology}

Because of the shortage of empirical research on innovation management in the context of professional service firms, this study is exploratory to develop initial assumptions in order to understand innovation management in consulting firms. A multi-case study is adopted to gain a comprehensive and in-depth understanding of this phenomenon (Yin, 1994). The choice of the case study methodology is justified by its appropriateness to examine a relatively unexplored aspect (Eisenhardt, 1989). The unit of analysis is the firm. Because the sample consists of different types of consulting businesses, it will be possible to contrast results due to the opposite nature of their core focus on consulting. The firm size is small, medium or large, with either local or multinational operations.

Table 2 Case study sample characteristics

\begin{tabular}{clllc}
\hline Case & Consulting type & Size & Operations & $\begin{array}{c}\text { No. of } \\
\text { interviews }\end{array}$ \\
\hline A & Management & Large & Multinational & 1 \\
B & Engineering & Small & Local & 1 \\
C & Management & Medium & Local & 2 \\
D & Design & Small & Local & 1 \\
E & Management & Large & Multinational & 1 \\
F & Information technologies & Large & Multinational & 1 \\
G & Information technologies & Large & Multinational & 1 \\
H & Information technologies & Large & Multinational & 2 \\
I & Information technologies & Large & Multinational & 1 \\
\hline
\end{tabular}

The study was conducted in nine consulting firms in Spain between April and June 2016 (Table 2). The universe is formed by the 23 firms that are members of the Spanish Association of Consulting Firms. Therefore, the study sample comprises $39.1 \%$ of the consulting firms in Spain. Observations and a structured interview were performed to 
clarify and obtain more in-depth answers about the innovation management process. Interviews were conducted with people responsible for the innovation management process, either a partner or senior manager. All our interviews lasted between 45 and 90 minutes and were transcribed and codified afterwards.

To increase the reliability and validity of the results, data collection and analysis were performed using the triangulation method, and the semi-structured interview was pretested to ensure that we obtained the responses that needed to be contrasted with the theory later (Bryman and Bell, 2003).

\section{Results and discussion}

\subsection{Innovation processes at consulting firms}

The innovation processes at consulting firms are distinguished according to the locus of innovation; in other words, they are categorised based on the actor who makes innovation happen, whether intentionally or not. This actor or source of knowledge for innovation could be internal or external to the organisation.

Table 3 compiles our findings on innovation processes, which are divided into three main categories based on whether they are internal, external and mixed. The internal category consists of innovation processes in which the initial push or creative idea for innovation comes from within the firm. The external category comprises innovation processes in which the initial push or creative idea comes from outside the firm. Finally, the mixed category includes innovation processes in which the initial push or creative idea comes from joint efforts of entities internal and external to the firm.

Table 3 Innovation processes identified in the case studies

\begin{tabular}{|c|c|c|c|c|c|c|c|}
\hline \multirow[b]{2}{*}{ Case } & \multicolumn{3}{|c|}{ Internal } & \multicolumn{2}{|c|}{ Mixed } & \multicolumn{2}{|c|}{ External } \\
\hline & $\begin{array}{c}\text { Management } \\
\text { driven } \\
\text { innovation }\end{array}$ & $\begin{array}{l}\text { Technology- } \\
\text { driven } \\
\text { innovation }\end{array}$ & $\begin{array}{c}\text { Employee- } \\
\text { driven } \\
\text { innovation }\end{array}$ & $\begin{array}{c}\text { Employee } \\
\text { involved in } \\
\text { user } \\
\text { innovation }\end{array}$ & $\begin{array}{l}\text { Open-driven } \\
\text { innovation }\end{array}$ & $\begin{array}{l}\text { Policy-driven } \\
\text { innovation }\end{array}$ & $\begin{array}{c}\text { User- } \\
\text { driven } \\
\text { innovation }\end{array}$ \\
\hline A & $\mathrm{X}$ & & & $X$ & & & \\
\hline B & & & & $\mathrm{X}$ & & $\mathrm{X}$ & \\
\hline $\mathrm{C}$ & $X$ & $X$ & & $\mathrm{X}$ & $\mathrm{X}$ & & \\
\hline $\mathrm{D}$ & & & & $\mathrm{X}$ & & & \\
\hline E & $\mathrm{X}$ & $X$ & $\mathrm{X}$ & $\mathrm{X}$ & $\mathrm{X}$ & & $\mathrm{X}$ \\
\hline $\mathrm{F}$ & $\mathrm{X}$ & $\mathrm{X}$ & $\mathrm{X}$ & $X$ & & & \\
\hline G & $\mathrm{X}$ & $X$ & $\mathrm{X}$ & $\mathrm{X}$ & $\mathrm{X}$ & & $\mathrm{X}$ \\
\hline $\mathrm{H}$ & $\mathrm{X}$ & $X$ & & $X$ & $X$ & $\mathrm{X}$ & \\
\hline I & & $X$ & & $X$ & & $X$ & \\
\hline
\end{tabular}

Three of these seven innovation processes emerge from the literature review and the other four from the data analyses. According to the Model for Innovation Processes in Services, there are three innovation processes: 
- Management-driven innovation. Six cases (A, C, E, F, G and H) presented evidence of this type of innovation process. Some of the tools, activities and structures to develop, promote, evaluate, foster and reward ideas include the use of an innovation intranet, in which employees can be informed about news related to innovation, events and projects within the organisation related to this field. Some of them also have blogs in each department or a key champion within the organisation that keeps the audience informed. Some intranets also have forums in a wiki format, in which employees can ask a question and be involved in different discussions with their coworkers, bosses and subordinates. The top management of the firm also provides employees with software that helps them to organise their ideas as well as project tracking and knowledge management systems, in which the details, deliverables and lessons learned are stored and indexed. Training is also provided on methodologies for creativity, negotiation, project management (Agile and Scrum) and innovation (design thinking and design-driven innovation). The most structured firms have also created an innovation management office and the role of a chief innovation officer (CIO), who is in charge of articulating the initiatives and resources needed to pursue an innovation objective within and outside the firm. Many of these improvements are organisational or management innovations, which refer to the invention and implementation of management practice, process, structure or technique that is new to the firm and aims to contribute to the achievement of organisational goals (Birkinshaw et al., 2008). A manager of the consulting firm $\mathrm{H}$ states: 'Organisationally, there is an innovation department with a chief innovation officer that reports directly to the CEO. This department is separated from the sectorial, regional and offerings divisions. The main duty is the reuse of capacities and experiences'.

- Employee-driven innovation. Three cases (E, F and G) presented evidence of this type of innovation process. The innovation mechanisms provided by the top management of the firm (management-driven innovation) is combined with the individual skills of the employees (consultants). A few companies have created a platform for idea generation and empower its use by creating competitions among employees with the aim of solving a specific problem or addressing a particular challenge, which is usually related to the organisation's interest or business. It is important to note that employees informally share ideas during coffee breaks, lunch and hallway encounters, and these ideas are not put into practice unless they are delivered to the right person or if employees are entrepreneurial enough to sell their ideas within the firm or with the client. It is also common for companies to incentivise these creative employees by having them on a special fast track to rise more quickly in the organisation and having assignments in projects across different disciplines (Fischer, 2011). The manager of the consulting firm $\mathrm{G}$ explains: 'We allow our employees to have their personal projects on a part-time basis. ... We believe as well in flexible models that big American companies such as Google have incorporated, such as the policy of employees having up to $20 \%$ of their time for their personal projects. We foster creativity... the knowledge that the employee is developing in that personal idea will be applied inside the firm ... so we have to be flexible on that'.

- Employees are involved in user innovation. All cases presented this type of innovation process. Nowadays, consultants recognise the importance of user 
participation and its integration during the delivery of service by sharing knowledge, problems and ideas that turn into innovative solutions, trying to exceed the clients' expectations. Consequently, the user has evolved from a role as co-producer to a position as co-creator (Gebauer et al., 2013; Santos-Vijande et al., 2013). With respect to this, the head of innovation at the consulting firm E said: 'Especially in this part, clients play a relevant role what we are explaining here, we do it with the input from clients'.

And four innovation processes were identified:

- Technology-driven innovation, in which research on radical technological changes within the firm is the main priority. Six cases (C, E, F, G, H and I) presented evidence of this type of innovation process. These examples correspond to information technology (IT) consulting firms, which focus on digital innovation in five primary services: cloud, mobile, the internet of things, big data and analytics, and software development. Some authors studied the business logic that emphasises the importance of strategies based on the digitisation of processes (Grant et al., 2013; Nylén and Holmström, 2014). Digitisation gives companies new opportunities for driving their business and, at the same time, transforms operations processes, business processes and customer experience. A manager at consulting firm I stated: 'Before we were just developing apps and focused on cloud computing and big data. Currently, we are emphasising machine learning, or "marching intelligence" as we call it, and we are trying to launch more projects abroad'.

- Open innovation, in which the exchange of knowledge and activities between the organisation and external entities is the primary purpose of innovation. Four cases $(\mathrm{C}, \mathrm{E}, \mathrm{G}$ and $\mathrm{H})$ presented evidence of this type of innovation process. A new universal practice is that consulting firms participate in venture capital activities. They are creating spin-offs seeded by ideas from employees, users or the public, especially those that are related to their service offering portfolio. If the firm perceives that the new business model is disruptive and successful, it most probably will be acquired and integrated it as another business unit (Puranam et al., 2006; Rubalcaba et al., 2016). In addition, the traditional collaboration with suppliers, project partners, universities and research centres prevails to create a coordinated innovation ecosystem in which consulting firms tend to be the hub (Chesbrough, 2010; Wallin and Von Krogh, 2010; Ritala and Hurmelinna-Laukkanen, 2013). A quotation from a manager at the consulting firm $\mathrm{H}$ exemplifies this: 'We have our ecosystem, which is evolving if you take a picture of our partners five years ago, and you look at it now, it changes due to mergers, acquisitions, alliances, etc. We evolve along with the ecosystem'.

- Policy-driven innovation. Three cases (B, H and I) presented evidence of this type of innovation process, which is driven by constraints in the environment usually created by an external actor. For example, some companies became innovative to obtain a tax benefit from these activities or, in other cases, changes in legislation allowed them to offer new services to clients in the banking and telecom industry. This type of innovation process expands the scope of actions to create new offers of services or the use of certain practices or technologies favouring the creation of collaborative 
networks in knowledge-intensive sectors (Salavisa et al., 2012). Nowadays, not only clients but also governments require the creation of sustainable offers in the service industry (Moisescu, 2018). In this context, a manager in the consulting firm B said: 'Sometimes there is no evolution of an idea, or no additional value is delivered according to the client's expectations. The reason for this is the type of our projects; public bids have a limited scope and defined time that must be respected'.

- User-driven innovation. Two cases (E and $G$ ) presented evidence of this type of innovation process, where users are the centre of the innovation. As mentioned by the head of innovation at the consulting firm E, 'There is also a fourth component in innovation, which is the focus in the client. We do not focus innovation in the revision of our internal processes, but in what has to do with the client'. Clients and users provide the innovative ideas that firms should further develop and implement. Some firms only come up with new offerings when a client requires it. Otherwise, they maintain the original service portfolio. The involvement of users in innovation brings new ideas, but firms can struggle to implement them, as doing so requires a customised innovation process and organisational structures to succeed (Magnusson et al., 2003; Oliveira and von Hippel, 2011; Peine et al., 2014).

\subsection{Innovation capabilities at consulting firms}

Table 4 shows that all consulting firms possess the same two capabilities for 'signalling user needs' and 'co-producing and orchestrating', which is explained because the service needs the client to participate during the process, and the consultants are experts in making the best use of the resources if a problem arises during the provision of the service so that the highest value can be delivered (Werr and Stjernberg, 2003). Conversely, the '(un-)bundling' capability is the scarcest and mainly possessed by IT consulting firms that experience more disruptive innovation processes, and thus they need to have a flexible and adaptive organisation. A manager from consulting firm $G$ explains: 'What we think is fundamental is to have the client/consumer as a central axis to everything that we design, therefore we created focus group sessions with the potential user of the platform that we were to develop. We went for two weeks to the main spots in Madrid for international transfers, and we interviewed people coming out from this place, saying: hey, would you like to participate in a focus group? We incentivise them with a small compensation. We had them in our offices and showed the prototypes, asking which requirement they had for this type of services'.

It is important to note that the two capabilities most found at consulting firms depend highly on consultants that bring creative compliance while balancing the client's constraints with the firm's business goals (Morris et al., 2015). The traditional organisational model in PSF is based on the innovation provided by the team's composition. In this case, the senior consultants apply their knowledge to the application and training of junior consultants (Smets et al., 2012). Our results complement this view by identifying that external firm knowledge from users, start-ups and other ecosystem partners is also necessary to nurture some innovation processes.

Most consulting firms incorporate the rest of the capacities (conceptualising, scaling and stretching, learning and adapting), which means that the more formalised the process 
of innovation in the firm is, the greater the firm's capacity to survive in the market. Service innovation is a type of dynamic capability that might be event dependent and enables companies to sense, seize and transform their business (Eisenhardt and Martin, 2000).

Table 4 Service innovation capabilities identified in the case studies

\begin{tabular}{ccccccc}
\hline Case & $\begin{array}{c}\text { Signalling } \\
\text { user needs }\end{array}$ & Conceptualising & $\begin{array}{c}(\text { Un- }) \\
\text { bundling }\end{array}$ & $\begin{array}{c}\text { Co-producing and } \\
\text { orchestrating }\end{array}$ & $\begin{array}{c}\text { Scaling and } \\
\text { stretching }\end{array}$ & $\begin{array}{c}\text { Learning and } \\
\text { adapting }\end{array}$ \\
\hline A & $\mathrm{X}$ & $\mathrm{X}$ & & $\mathrm{X}$ & $\mathrm{X}$ & $\mathrm{X}$ \\
$\mathrm{B}$ & $\mathrm{X}$ & & $\mathrm{X}$ & & \\
$\mathrm{C}$ & $\mathrm{X}$ & $\mathrm{X}$ & & $\mathrm{X}$ & $\mathrm{X}$ & $\mathrm{X}$ \\
$\mathrm{D}$ & $\mathrm{X}$ & & & $\mathrm{X}$ & & \\
$\mathrm{E}$ & $\mathrm{X}$ & $\mathrm{X}$ & $\mathrm{X}$ & $\mathrm{X}$ & $\mathrm{X}$ & $\mathrm{X}$ \\
$\mathrm{F}$ & $\mathrm{X}$ & $\mathrm{X}$ & $\mathrm{X}$ & $\mathrm{X}$ & $\mathrm{X}$ & $\mathrm{X}$ \\
$\mathrm{G}$ & $\mathrm{X}$ & $\mathrm{X}$ & $\mathrm{X}$ & $\mathrm{X}$ & $\mathrm{X}$ & $\mathrm{X}$ \\
$\mathrm{H}$ & $\mathrm{X}$ & $\mathrm{X}$ & $\mathrm{X}$ & $\mathrm{X}$ & $\mathrm{X}$ & $\mathrm{X}$ \\
$\mathrm{I}$ & $\mathrm{X}$ & & & $\mathrm{X}$ & $\mathrm{X}$ & \\
\hline
\end{tabular}

\subsection{Innovation dimensions at consulting firms}

Innovation dimension refers to the type of innovation outcome generated by the innovation process. The challenge of innovation in PSF is balancing between generating incremental innovation by exploiting current knowledge and creating radical innovations by exploring new ideas at the same time (Smets et al., 2012).

The results in Table 5 suggest that consulting firms tend to create new service offerings and new technology-based delivery systems. An example of this is expressed by the manager responsible for innovation at consulting firm I: 'The innovation area does not function as a department but as a series of labs. We have one lab focused on product design using the knowledge on new technologies. We have another lab with people in charge to explore for a more radical and futuristic innovation. And we have a central lab related to user experience'. As the interviews confirmed, this effect correlates with client requests and needs. On the one hand, clients usually ask for a way to reshape their current services or offer a new one, as well as the digitisation of their business models. This result refers to the interconnection that exists between product and process innovation, which represents the ambidexterity between exploitation and exploration activities in PSF, respectively (Smets et al., 2012; Morris et al., 2015). Then, after the process is digitised, space is opened up for a new product/service offer. To a minor degree, this type of service firm changes how value is captured in their revenue model and invests in new delivery systems that affect innovation at the employee, organisational and cultural level. On the other hand, consulting firms do not innovate very much in their business models when looking for new channels to interact with customers and find new alliances and suppliers. 
Table 5 Service innovation dimensions identified in the case studies

\begin{tabular}{ccccccc}
\hline Case & $\begin{array}{c}\text { New } \\
\text { service } \\
\text { concept }\end{array}$ & $\begin{array}{c}\text { New } \\
\text { customer } \\
\text { interaction }\end{array}$ & $\begin{array}{c}\text { New } \\
\text { business } \\
\text { partner }\end{array}$ & $\begin{array}{c}\text { New } \\
\text { revenue } \\
\text { model }\end{array}$ & $\begin{array}{c}\text { New delivery system: } \\
\text { personnel, organisation } \\
\text { and culture }\end{array}$ & $\begin{array}{c}\text { New delivery } \\
\text { system: } \\
\text { technological }\end{array}$ \\
\hline $\mathrm{A}$ & $\mathrm{X}$ & & & $\mathrm{X}$ & $\mathrm{X}$ & $\mathrm{X}$ \\
$\mathrm{B}$ & $\mathrm{X}$ & & $\mathrm{X}$ & $\mathrm{X}$ & $\mathrm{X}$ & $\mathrm{X}$ \\
$\mathrm{C}$ & $\mathrm{X}$ & & $\mathrm{X}$ & $\mathrm{X}$ & & $\mathrm{X}$ \\
$\mathrm{D}$ & & $\mathrm{X}$ & $\mathrm{X}$ & & $\mathrm{X}$ & $\mathrm{X}$ \\
$\mathrm{E}$ & $\mathrm{X}$ & $\mathrm{X}$ & $\mathrm{X}$ & & $\mathrm{X}$ & $\mathrm{X}$ \\
$\mathrm{F}$ & $\mathrm{X}$ & & $\mathrm{X}$ & $\mathrm{X}$ & $\mathrm{X}$ & $\mathrm{X}$ \\
$\mathrm{G}$ & $\mathrm{X}$ & $\mathrm{X}$ & & & $\mathrm{X}$ & $\mathrm{X}$ \\
$\mathrm{H}$ & $\mathrm{X}$ & & & & & \\
$\mathrm{I}$ & $\mathrm{X}$ & & & & & \\
\hline
\end{tabular}

\section{Conclusions}

Companies struggle to find the best way to manage innovation according to their ecosystem. They cope with internal (managers and employees) as well as external actors (clients, competitors, suppliers, investors, government and society) that require different ad-hoc innovation processes and capabilities within the firm. The result of these innovation processes is innovation output that is either incremental or radical.

Consulting firms make strategic choices to select, develop and maintain a mix of innovation processes. This result goes beyond the mere fact of addressing the management of innovation. It might also represent a business model with a new shape because changes affect aspects such as the value proposition, activities, resources, partners, types of clients, distribution channels, cost structure and revenue modality.

The research explores how consulting firms organise to manage innovation from a process perspective as well as its relationship with innovation capabilities and dimensions. Consulting firms tend to simplify reality by trying to control a single linear innovation process, but in fact, several innovation processes operate at the same time. The results reflect that all these processes are not mutually exclusive; on the contrary, many of them coexist or evolve into the other along the lifecycle of the firm and its particular business circumstances.

The results also show seven different innovation processes that affect the typology of the innovation management system at consulting firms and that are divided into three groups: internal (management-driven, technology-driven and employee-driven innovations), mixed (employee involved in user innovation and open innovation) and external (policy-driven and user-driven innovations). Because of the analytical approach used in this type of organisation to structure work and the role of the client in consulting services, most of the case studies present management-driven innovation and employees involved in user innovation processes. The implementation of these processes contributes to their formalisation, which implies the incorporation of top-down and bottom-up mechanisms, the creation of an innovative culture, and the training of people in innovation and how it can be achieved. These actions create an appropriate environment and the consolidation of new structures that were previously based on the informal 
exchange of knowledge. This practice could be extended to other knowledge-based service firms and in which human capital is the main element of management, such as banking or telecommunication. This approach contrasts with other innovation processes identified in PSF, such as client-driven product innovation and internally driven process innovation.

The innovation processes used by consulting firms also condition the capabilities and dimensions of innovation. The primary capabilities shown in the case studies are 'signalling user needs' and 'co-producing and orchestrating', in which two aspects are of interest. On the one hand, most firms lack (un)-building capability, which means that changes at the organisational level are more difficult to implement. However, IT consulting firms incorporate this dynamic capability, because they act in more competitive environments that require them to be more flexible to maintain the capacity for innovation. On the other hand, consulting firms with more dynamic capabilities tend to show a greater diversity of innovation dimensions as a result of innovation processes. This finding is in line with a recent study that correlates innovation capabilities and types of innovation at service firms (Rajapathirana and Hui, 2017). Regarding the dimensions of innovation, the results highlight a greater emphasis on changes in the current process to provide new service concepts or new service delivery systems (whether technological or not). This is the case with IT consulting firms, which are extending their business models beyond offering services to offer digital products as well. This strategy can be called 'productisation', as opposed to 'servitisation' (Tether, 2013).

The study also provides relevant insight for managers of consulting firms in understanding how best to define the typology of the innovation process, capabilities and dimensions when designing their innovation management strategy at their companies. This will help them to reduce the associated risks and obtain competitive advantages that will translate into higher benefits.

Finally, one limitation of the study is the need to cover other variables on innovation in the context of consulting firms, such as interlinks between the innovation management processes and the innovation type, innovation degree and external and internal drivers. These factors imply the design of the innovation strategy and innovation processes that consulting firms adopt, according to the characteristics of the firm, such as the type of consulting firm, size and country. Future research should focus on these types of studies, including quantitative methods to generalise the results.

\section{Acknowledgements}

This paper is produced as part of the EMJD program European Doctorate in Industrial Management (EDIM) funded by the European Commission, Erasmus Mundus Action. The authors thank the National Science and Technology Council of Mexico (CONACyT) for its contribution in supporting this research. 


\section{References}

Anand, N., Gardner, H. and Morris, T. (2007) 'Knowledge-based innovation: emergence and embedding of new practice areas in management consulting firms', Academy of Management Journal, Vol. 50, No. 2, pp.406-428.

Birkinshaw, J.M., Hamel, G. and Mol, M.J. (2008) 'Management innovation', Academy of Management Review, Vol.33, No. 4, pp.825-845.

Bouncken, R.B. and Kraus, S. (2013) 'Innovation in knowledge-intensive industries: the double-edged sword of coopetition', Journal of Business Research, Vol. 66, No. 10, pp.2060-2070.

Bryman, A. and Bell, E. (2003) Business Research Methods, Oxford University Press, Oxford, UK.

Chae, B. (2012) 'An evolutionary framework for service innovation: insights of complexity theory for service science', International Journal of Production Economics, Vol. 135, No. 2, pp.813-822

Chae, B. (2014) 'A complexity theory approach to IT-enabled services (IESs) and service innovation: business analytics as an illustration of IESs', Decision Support Systems, Vol. 57, pp.1-10.

Chatzoglou, P. and Chatzoudes, D. (2017) 'The role of innovation in building competitive advantages: an empirical investigation', European Journal of International Management, Vol. 21, No. 1, pp.44-69.

Chesbrough, H. (2010) 'Business model innovation: opportunities and barriers', Long Range Planning, Vol. 43,Nos. 2/3, pp.354-363.

Chesbrough, H. and Bogers, M. (2014) 'Explicating open innovation: clarifying an emergent paradigm for understanding innovation', in Chesbrough, H., Vanhaverbeke, W. and West, J. (Eds.): New Frontiers in Open Innovation, Oxford University Press, Oxford, UK, pp.3-28.

Crevani, L., Palm, K. and Schilling, A. (2011)'Innovation management in service firms: a research agenda', Service Business, Vol. 5, No. 2, pp.177-193.

den Hertog, P. (2000) 'Knowledge-intensive business services as co-producers of innovation', International Journal of Innovation Management, Vol. 4, No. 4, pp.491-528.

den Hertog, P., van der Aa, W. and de Jong, M.W. (2010) 'Capabilities for managing service innovation: towards a conceptual framework', Journal of Service Management, Vol. 21, No. 4, pp.490-514.

Droege, H., Hildebrand, D. and Forcada, M. (2009) 'Innovation in services: present findings, and future pathways', Journal of Service Management, Vol. 20, No. 2, pp.131-155.

Eisenhardt, K.M. (1989) 'Building theories from case study research', Academy of Management Review, Vol.14, No. 4, pp.532-550.

Eisenhardt, K.M. and Martin, J. (2000) 'Dynamic capabilities: what are they?', Strategic Management Journal, Vol. 21, Nos. 10/11, pp.1105-1121.

European Commission (2012a) The Smart Guide to Service Innovation. How to Better Capitalise on Service Innovation for Regional Structural Change and Industrial Modernization, Directorate-General for Enterprise and Industry, Brussels.

European Commission (2012b) Knowledge-Intensive (business) Services in Europe, DirectorateGeneral for Research and Innovation, Brussels.

Fischer, A. (2011) 'Recognizing opportunities: initiating service innovation in PSFs', Journal of Knowledge Management, Vol. 15, No. 6, pp.915-927.

Furseth, P.I. and Cuthbertson, R. (2013) 'The service innovation triangle: a tool for exploring value creation through service innovation', International Journal of Technology Marketing, Vol. 8, No. 2, pp.159-176

Gebauer, J., Füller, J. and Pezzei, R. (2013) 'The dark and the bright side of co-creation: triggers of member behavior in online innovation communities', Journal of Business Research, Vol.66, No. 9, pp.1516-1527. 
Grant, K., Alefantos, T., Meyer, M. and Edgar, D. (2013) 'Capturing and measuring technologybased service innovation - a case analysis within theory and practice', International Journal of Information Management, Vol. 33, No. 5, pp.899-905.

Hidalgo, A. and D'Alvano, L. (2014)'Service innovation: Inward and outward related activities and cooperation mode', Journal of Business Research, Vol. 67, No. 5, pp.698-703.

Janssen, M.J., Castaldi, C. and Alexiev, A. (2016) 'Dynamic capabilities for service innovation: conceptualization and measurement', R\&D Management, Vol. 46, No. 4, pp.797-811.

Kaynak, S., Altuntas, S. and Dereli, T. (2017) 'Comparing the innovation performance of EU candidate countries: an entropy-based TOPSIS approach', Economic Research-Ekonomska Istraživanja, Vol. 30, No. 1, pp.31-54.

Lemus-Aguilar, I. and Hidalgo, A. (2015) 'Innovation in consulting firms: an area to explore', in Cortés, P., Maeso-González, E. and Escudero-Santana, A. (Eds): Enhancing Synergies in a Collaborative Environment, Springer, Switzerland, pp.335-342.

Maglio, P.P. and Spohrer, J. (2008) 'Fundamentals of service science', Journal of the Academy of Marketing Science, Vol. 36, No. 1, pp.18-20.

Maglio, P.P. and Spohrer, J. (2013) 'A service science perspective on business model innovation', Industrial Marketing Management, Vol. 42, No. 5, pp.665-670.

Magnusson, P.R., Matthing, J. and Kristensson, P. (2003) 'Managing user involvement in service innovation: experiments with innovating end users', Journal of Service Research, Vol. 6, No. 2, pp.111-124.

Moisescu, O.I. (2018) 'From perceptual corporate sustainability to customer loyalty: a multisectorial investigation in a developing country', Economic Research-Ekonomska Istraživanja, Vol. 31,No. 1, pp.55-72.

Morris, T., Smets, M. and Greenwood, R. (2015) 'In pursuit of creative compliance: Innovation in professional service firms', in Bryson, J.R. and Daniels, P.W. (Eds): Handbook of Service Business: Management, Marketing, Innovation, and Internationalisation,Edward Elgar Publishing, Cheltenham, pp.301-315.

Nylén, D. and Holmström, J. (2014) 'Digital innovation strategy : a framework for diagnosing and improving digital product and service innovation', Business Horizons, Vol. 58, No. 1, pp.57-67.

Öberg, C. and Alexander, A.T. (2018) 'The openness of open innovation in ecosystems integrating innovation and management literature on knowledge linkages', Journal of Innovation \& Knowledge, in press. Available online at: https://doi.org/10.1016/ j.jik.2017.10.005

OECD (2005) Summary Report of the Study on Globalisation and Innovation in the Business Service Sector, Paris.

Oliveira, P. and von Hippel, E. (2011) 'Users as service innovators: the case of banking services', Research Policy, Vol. 40, No. 6, pp.806-818.

Peine, A., Rollwagen, I. and Neven, L. (2014) 'The rise of the "innosumer" - rethinking older technology users', Technological Forecasting and Social Change, Vol. 82, No. 1, pp.199-214.

Phillips, N. (2013) 'Organizing innovation', in Dodgson, M., Gann, D. and Phillips, N. (Eds): The Oxford Handbook of Innovation Management, Oxford University Press, Oxford, UK, pp.482-504.

Poutanen, P., Soliman, W. and Stahle, P. (2016) 'The complexity of innovation: an assessment and review of the complexity perspective', European Journal of International Management, Vol. 19, No. 2, pp.189-213.

Puranam, P., Singh, H. and Zollo, M. (2006) 'Organizing for innovation: managing the coordination-autonomy dilemma in technology acquisitions', Academy of Management Journal, Vol. 49, No. 2, pp.263-280.

Rajapathirana, R. J. and Hui, Y. (2017) 'Relationship between innovation capability, innovation type, and firm performance', Journal of Innovation \& Knowledge, Vol. 3, No. 1, pp.44-55. 
Ritala, P. and Hurmelinna-Laukkanen, P. (2013) 'Incremental and radical innovation in coopetition-the role of absorptive capacity and appropriability', Journal of Product Innovation Management, Vol. 30, No. 1, pp.154-169.

Rubalcaba, L., Aboal, D. and Garda, P. (2016) 'Service innovation in developing economies: evidence from Latin America and the Caribbean', The Journal of Development Studies, Vol. 52, No. 5, pp.607-626.

Rubalcaba, L., Michel, S., Sundbo, J., Brown, S.W. and Reynoso, J. (2012) 'Shaping, organizing, and rethinking service innovation: a multidimensional framework', Journal of Service Management, Vol. 23, No. 5, pp.696-715.

Salavisa, I., Sousa, C. and Fontes, M. (2012) 'Topologies of innovation networks in knowledgeintensive sectors: sectoral differences in the access to knowledge and complementary assets through formal and informal ties', Technovation, Vol. 32, No. 6, pp.380-399.

Salunke, S., Weerawardena, J. and McColl-Kennedy, J.R. (2011) 'Towards a model of dynamic capabilities in innovation-based competitive strategy: insights from project-oriented service firms', Industrial Marketing Management, Vol. 40, No. 8, pp.1251-1263.

Salunke, S., Weerawardena, J. and McColl-Kennedy, J.R. (2012) 'Competing through service innovation: the role of bricolage and entrepreneurship in project-oriented firms', Journal of Business Research, Vol. 66, No. 8, pp.1085-1097.

Santos-Vijande, M.L., González-Mieres, C. and López-Sánchez, J.A. (2013) 'An assessment of innovativeness in KIBS: Implications on KIBS' co-creation culture, innovation capability, and performance', Journal of Business \& Industrial Marketing, Vol. 28, No. 2, pp.86-102.

Smets, M., Morris, T. and Malhotra, N. (2012) 'Changing career models and capacity for innovation in professional services', in Reihlen, M. and Werr, A. (Eds): Handbook of Research on Entrepreneurship in Professional Services, Edward Elgar Publishing, Cheltenham, pp.148-169.

Tether, B.S. (2013) 'Services, innovation, and managing service innovation', in Dodgson, M., Gann, D. and Phillips, N. (Eds): The Oxford Handbook of Innovation Management, Oxford University Press, Oxford, UK, pp.600-624.

Tidd, J. and Bessant, J. (2013) Managing Innovation Integrating Technological, Market and Organizational Change, Wiley, London, UK.

Trigo, A. and Vence, X. (2012) 'Scope and patterns of innovation cooperation in Spanish service enterprises', Research Policy, Vol. 41, No. 3, pp.602-613.

Vargo, S.L. and Lusch, R.F. (2004) 'Evolving to a new dominant logic', Journal of Marketing, Vol. 68, No. 1, pp.1-17.

Verganti, R. (2010) Design-Driven Innovation, Harvard Business Press, Boston, MA.

von Nordenflycht, A. (2010) 'What is a professional service firm? Toward a theory and taxonomy of knowledge-intensive firms', Academy of Management Review, Vol. 35, No. 1, pp.155-174.

Wallin, M.W. and Von Krogh, G. (2010) 'Organizing for open innovation: focus on the integration of knowledge', Organizational Dynamics, Vol. 39, No. 2, pp.145-154.

Werr, A. and Stjernberg, T. (2003) 'Exploring management consulting firms as knowledge systems', Organization Studies, Vol. 24, No. 6, pp.881-908.

Yin, R. (1994) Case Study Research: Design and Methods, Sage, Thousand Oaks, CA. 